\title{
Direct and Residual Effects of Different Poultry Compost and NPK Fertilizer Applications on Drought-Tolerant Maize Production
}

\author{
O. M. Otitoju ${ }^{1}$, M. B. Adewole ${ }^{1}$, A. A. Olowoake ${ }^{2}$ \& A. O. Ilesanmi ${ }^{1}$ \\ ${ }^{1}$ Institute of Ecology and Environmental Studies, Obafemi Awolowo University, Ile-Ife, Nigeria \\ ${ }^{2}$ Department of Crop Production, Kwara State University, Malete, Ilorin, Nigeria \\ Correspondence: Moses B. Adewole, Institute of Ecology, Obafemi Awolowo University, Ile-Ife, Nigeria. Tel: \\ 234-80-3478-4267. E-mail: badewole@oauife.edu.ng
}

Received: August 7, 2015 Accepted: November 19, 2015 Online Published: July 30, 2016

doi:10.5539/jsd.v9n4p61 URL: http://dx.doi.org/10.5539/jsd.v9n4p61

\begin{abstract}
This study investigated the direct and residual effects of different poultry compost and NPK fertilizer applications on the growth components of drought-tolerant maize (Zea mays L.) in a derived savanna agroecology of southwestern Nigeria. The experiment was laid out in a Randomized Complete Block Design (RCBD) with six treatments, each replicated thrice. The treatments which were applied at planting, consisted of $100 \%$ cockerel manure (CM), 100\% broiler manure (BM), 100\% layers manure (LM), 33.3\% cockerel manure + $33.3 \%$ Broiler manure $+33.3 \%$ Layers manure (CBLM) at $4.50 \mathrm{~kg} \mathrm{plot}^{-1}$, inorganic NPK 20-20-10 fertilizer at $0.30 \mathrm{~kg} \mathrm{plot}{ }^{-1}$ and zero manure application as control (CT). The apparent efficiency of $\mathrm{N}$ recovery (AENR), $\mathrm{N}$ and $\mathrm{P}$ ear-leaf (NPEL) contents of maize with poultry manures were higher when compared to inorganic NPK fertilizer applications. The highest mean grain yield $1.30 \mathrm{t} \mathrm{ha}^{-1}$ of maize was obtained with BM treatment that had the highest AENR and NPEL values. This however, was not significantly $(p>0.05)$ different from the mean grain yield obtained with other treatments during the dry season. Comparable but higher mean grain yield, but also not significantly $(\mathrm{p}>0.05)$ different were obtained during the wet season in all the treatments.
\end{abstract}

Keywords: derived savanna, drought-tolerant maize, maize ear-leaf, $\mathrm{N}$ efficiency, poultry manure, seasonal variation

\section{Introduction}

Maize (Zea mays L.) is an annual cereal crop commonly cultivated in most parts of Nigeria. It is a major source of food and livelihood for millions of people in many countries of the world (Ogunsumi et al., 2005). Maize grains are useful raw material in industries for the production of medicines and different food recipes (Oladejo and Adetunji, 2012). Maize has a multipurpose advantage as every part of it such as the leaves, stalks, tassels and cobs are useful (IITA, 2001). In Nigeria, the increasing rate of demand for maize for different purposes had not been met with the supply from local production (Daramola and Taiwo, 2008).

Climate change is considered as posing the greatest challenge to agriculture and food security in sub-Saharan Africa. This is because the region is vulnerable to climatic change and its coping capacity is perceived to be very low (Li et al., 2009). Agriculture is very sensitive to climate change to the extent of forcing farmers to drop their choice of crop, maize for millet that requires limited rainfall (Odjugo, 2010). Odjugo (2011) observed further that one of the adaptation measures to crop production in Nigeria was the distribution of early maturing crops to the resource-poor farmers. Planting of drought-tolerant crops such as maize could serve as additional measure in response to the prevailing changing climatic conditions. According to Ayoade (2011), drought is a major factor responsible for crop production and productivity decline in the temperate and tropical regions of the world. The use of drought-tolerant maize cultivars with high yielding potential to cope with the present climate change scenarios (Schittenhelm and Schroetter, 2014) is therefore important since access to drought-tolerant maize variety may be the only alternative mitigating option available to resource-poor African farmers (Tsai et al., 1984).

The use of manure in crop husbandry helps to preserve the ecosystem (Farhad et al., 2009), as the substantial residual effect on the succeeding crop cultivation cannot be overemphasized (Reddy et al., 2004). Adeoye et al. (1995) observed that the use of organic-based fertilizer to enhance the fertility of the soil was a good soil 
management strategy for the low activity clay African soils, particularly Nigeria. Poultry compost is an organic-based fertilizer, when properly applied to soil, enhanced its physical and chemical properties (Boateng et al., 2006; Farhad et al., 2009). The increasing demand for poultry meat, particularly during festive periods (Awe et al., 2014) and its acceptance by most societies due to its relatively low cholesterol content had led to increase in the number of large poultry farms in Nigeria (Otitoju, 2014). However, the environmental pollution arising due to uncontrolled and indiscriminate disposal of poultry droppings and their feathers are increasing.

There is therefore, a need to convert poultry waste into harmless and environment-friendly composted manure which could be useful in crop husbandry. However, since different bird-types such as cockerel, broilers and layers are fed with different feed-types because of the different purposes for which the birds are meant to achieve, their droppings' properties would therefore vary. Preliminary screenhouse studies of Adewole and Dedeke (2012) observed variations on growth performance, biomass yield and nutritional composition of Amaranthus cruentus to different birds' composts. However, there is scanty information on the specific type of the poultry manure that would give the best result in terms of growth performance and yield of maize. This study therefore aims at comparing the direct and residual effects of different poultry composts and inorganic fertilizer applications on the agronomic performance and yield of a drought-tolerant maize variety in two seasons.

\section{Methods}

\subsection{Description of the Experimental Site}

The experiment was conducted at the Teaching and Research Farm of the Institute of Agricultural Research and Training (IAR \&T) Substation, Ilora, Afijio Local Government of Oyo State, a derived savanna zone of Southwestern Nigeria. The study site lies on latitude $07^{\circ} 48^{\prime} 50.6^{\prime \prime} \mathrm{N}$ and longitude $003^{\circ} 48^{\prime} 55.6^{\prime \prime} \mathrm{E}$. The soil texture of the study site was loamy sand with relatively low soil fertility status as presented in Table 1 . The selected meteorological data for 2012 and 2013 of the station are presented in Figure 1 (a-c).

\subsection{Experimental Design, Layout and Other Cultural Operations}

The experimental plot was cleared manually and three composite soil samples were taken for pre-soil analysis. The experiment consisted of three $23.0 \mathrm{~m} \times 2.5 \mathrm{~m}$ blocks; each block was in turn divided into six plots of $3.0 \mathrm{~m} \mathrm{x}$ $2.5 \mathrm{~m}$ with an alley of $1.0 \mathrm{~m}$ between blocks and $1.0 \mathrm{~m}$ within plots. The experiment was laid out in a randomized complete block design with six treatments and each treatment was replicated three times to give a total of 18 plots. The treatments consisted of $100 \%$ cockerel manure (CM), $100 \%$ broiler manure (BM), $100 \%$ layers manure (LM), $33.3 \%$ cockerel manure $+33.3 \%$ Broiler manure $+33.3 \%$ Layers manure (CBLM) at 4.50 $\mathrm{kg} \mathrm{plot}^{-1}$, NPK 20-20-10 at 0.30 $\mathrm{kg} \mathrm{plot}^{-1}$ (IF) and zero manure application as control (CT).

Seeds of drought-tolerant maize variety, DT-SR- $\mathrm{WC}_{2}$ were obtained from IAR \&T, Ibadan and planted at three seeds per hole using $75 \mathrm{~cm} \times 50 \mathrm{~cm}$ planting distance. The maize seedlings were later thinned to two stands per hole at two weeks after planting (WAP) to give a total of 53,333 plants population per hectare. The experiment was carried out in the dry and wet seasons of 2012 and 2013 respectively. Soil amendments were applied only at sowing time of the first season. Data on growth performance such as plant height, number of leaves and stem girth were collected forthnightly from two weeks after planting (WAP) and continued till 8 WAP when the oldest leaves of the test crop began to fall off. All the plots were manually weeded using hand hoe at 2, 5 and 7 WAP.

\subsection{Soil Sampling, Sample Preparation and Analysis}

Three composite topsoil $(0-15 \mathrm{~cm})$ samples for pre-soil and 54 for post-soil tests were collected using simple random sampling technique, air-dried and sieved through a 2-mm mesh to remove debris and stones prior to analyses. Fresh droppings of cockerel, broiler and layers birds from a poultry farm were separately collected, heaped under a shed and allowed to compost aerobically for three months. The poultry heaps were stirred once in two weeks to enhance aeration and composting. The poultry composts were air-dried, ground and analysed for their chemical properties.

The properties of soil and manure samples were analysed using standard methods (Page et al., 1982). The soil $\mathrm{pH}$ was determined in 1:1 soil-water suspension using a glass electrode $\mathrm{pH}$ meter. Total nitrogen of the soil and manure were determined by the macro-Kjeldahl method. Available phosphorus in the soil and manure were extracted using Bray P1 method and P in the extractants was determined by colorimeter. The soil and manure organic carbon were determined using Walkley-Black wet oxidation method. Calcium ion, $\mathrm{Mg}^{2+}$ and $\mathrm{K}^{+}$ concentrations in the soil and manure were extracted using $1 \mathrm{M}$ ammonium acetate buffered at $\mathrm{pH} 7.0$ and their concentrations in the extracts were measured using Buck Scientific Model 200 (East Norwalk, Connecticut, USA) Atomic Absorption Spectrophotometer. 
Table 1. Physico-chemical properties of the soil used in the experiment

\begin{tabular}{|c|c|}
\hline Property & Value \\
\hline pH (1:1 soil-water) & 5.85 \\
\hline Organic Carbon $\left(\mathrm{g} \mathrm{kg}^{-1}\right)$ & 9.81 \\
\hline Total Nitrogen $\left(\mathrm{g} \mathrm{kg}^{-1}\right)$ & 0.70 \\
\hline Sand $\left(\mathrm{g} \mathrm{kg}^{-1}\right)$ & 720.00 \\
\hline Silt $\left(\mathrm{g} \mathrm{kg}^{-1}\right)$ & 230.00 \\
\hline Clay $\left(\mathrm{g} \mathrm{kg}^{-1}\right)$ & 50.00 \\
\hline Textural class & Loamy sand \\
\hline $\mathrm{Na}^{+} \mathrm{cmol} \mathrm{kg}^{-1}$ & 0.42 \\
\hline $\mathrm{K}^{+} \mathrm{cmol} \mathrm{kg}{ }^{-1}$ & 0.35 \\
\hline $\mathrm{Ca}^{2+} \mathrm{cmol} \mathrm{kg}^{-1}$ & 0.75 \\
\hline $\mathrm{Mg}^{2+} \mathrm{cmol} \mathrm{kg}^{-1}$ & 0.28 \\
\hline Available Phosphorus (mg kg$\left.{ }^{-1}\right)$ & 9.44 \\
\hline $\mathrm{Zn}\left(\mathrm{mg} \mathrm{kg}^{-1}\right)$ & 0.14 \\
\hline $\mathrm{Fe}\left(\mathrm{mg} \mathrm{kg}^{-1}\right)$ & 0.20 \\
\hline $\operatorname{Mn}\left(\mathrm{mg} \mathrm{kg}^{-1}\right)$ & 0.17 \\
\hline Base saturation $(\%)$ & 93.11 \\
\hline
\end{tabular}


(a)

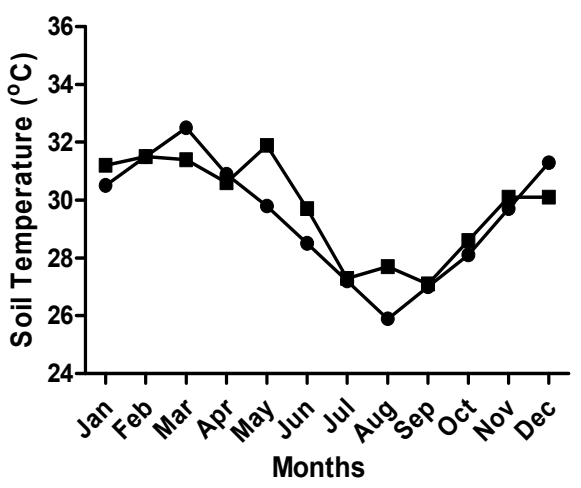

(b)

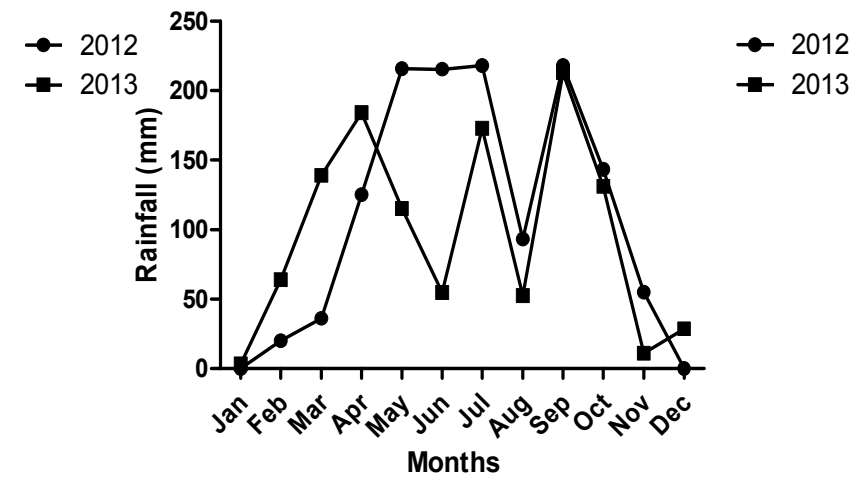

(c)

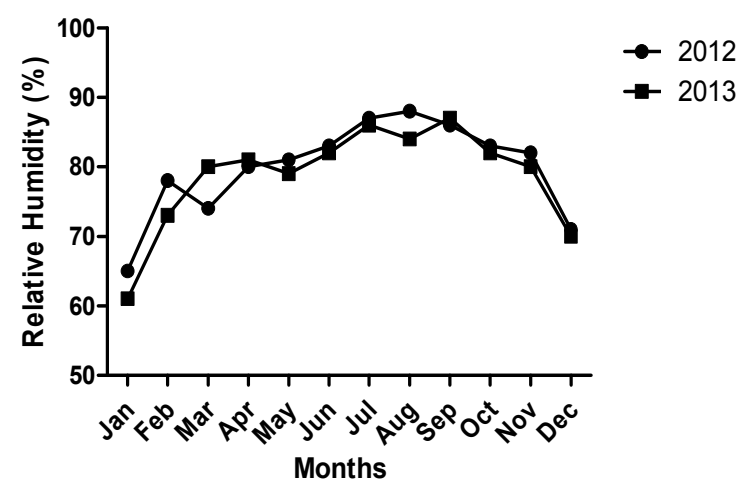

Figure 1. (a)-(c): Monthly (a) soil temperature, (b) rainfall and (c) relative humidity of the study area (2012-2013)

Source: Nigerian Meteorological Agency, Samonda, Ibadan

\subsection{Plant Sampling, Sample Preparation and Analysis}

At maize tasseling stage, six representative ear-leaf samples per plot were randomly harvested from all the treatments. These samples were thoroughly washed with distilled water, oven-dried for $48 \mathrm{~h}$ at $70{ }^{\circ} \mathrm{C}$. The dried plant samples were separately ground using stainless milling machine and thereafter sieved through $0.5 \mathrm{~mm}$ sieve. The $\mathrm{N}$ and $\mathrm{P}$ contents of maize ear-leaf plant samples were determined by the micro Kjeldahl and Bray P1 methods (Page et al., 1982) respectively.

Apparent efficiency of nitrogen recovery (AENR) otherwise called 'nitrogen efficiency' for the growing seasons was calculated using Rees and Castle (2002) approach. This is the difference between the $\mathrm{N}$ uptake by the maize plants in the plots with manure/fertilizer application and the control, divided by the $\mathrm{N}$ applied as given below:

$$
A E N R=\left(N_{\text {treatment }}-N_{\text {control }}\right) / N_{\text {applied }}
$$

where $\mathrm{N}_{\text {treatment }}$ is the nitrogen uptake by the maize plant when poultry manure and/or inorganic fertilizer were imposed, $\mathrm{N}_{\text {control }}$ is the nitrogen uptake by the maize plant in the control plots and $\mathrm{N}_{\text {applied }}$ is the nitrogen applied.

\subsection{Maize Grains Harvesting and Processing}

The ears of twenty-four maize plants in each plot that had earlier been randomly selected and tagged were 
manually harvested at 12 WAP and air-dried inside the maize crib to $12 \%$ moisture content. The maize grains were manually threshed, weighed and the experiment was terminated.

\subsection{Statistical Analysis}

Data obtained on maize yield were subjected to analysis of variance and their treatment means were separated at 95\% confidence limit using Statistical Analysis Software (SAS) version 9.2 package.

\section{Results and Discussion}

\subsection{Properties of Soil and Composted Poultry Manures}

The physical and chemical properties of the soil used for planting of maize are presented in Table 1 . The soil $\mathrm{pH}$ in 1:1 soil to water suspension was 5.85 indicating acidic soil conditions. The soil had 720.00, 230.00 and 50.00 $\mathrm{g} \mathrm{kg}^{-1}$ as the proportions of sand, silt and clay respectively, thus indicating loamy sand soil texture. The pre-soil organic carbon $9.81 \mathrm{~g} \mathrm{~kg}^{-1}$; total nitrogen $0.70 \mathrm{~g} \mathrm{~kg}^{-1}$, available $\mathrm{P} 9.44 \mathrm{mg} \mathrm{kg}^{-1}$ and cation exchangeable capacity $1.80 \mathrm{cmol} \mathrm{kg}^{-1}$ obtained, were considered low for maize cultivation in Nigeria (Adeoye and Agboola, 1985). Also, Alvarez and Grigera (2005) observed a direct relationship between soil nitrogen deficiency and reduced yield of maize. Kogbe and Adediran (2003) observed that nitrogen was a major yield-determining factor and its availability in sufficient quantity during the growing season is essential for optimum maize production. The chemical compositions of different composted poultry manures are presented in Table 2. Broiler composted manure had the highest values of organic carbon $381.30 \mathrm{~g} \mathrm{~kg}^{-1}, \mathrm{~N} 34.30 \mathrm{~g} \mathrm{~kg}^{-1}$ and P $18.30 \mathrm{~g} \mathrm{~kg}^{-1}$ with a C/N ratio of 11.12; a factor for the enhanced performance when compared with other treatments while cockerel had the lowest values.

\subsection{Growth Measurement of Maize}

The effects of different composted manure applications to soil on the height of maize plants in the two seasons of cultivation are presented on Figure $2(a-c)$. From 6 WAP, the plant height had significantly $(p<0.05)$ highest value in plot with $\mathrm{CM}$ and closely followed by $\mathrm{BM}$; while the control plot had least values in the dry season. Comparable observations were recorded, but with slightly higher values at $8 \mathrm{WAP}$ during the wet season. The residual effects of manure application from the first cultivation and the decayed maize crop residue could be responsible.

Table 2. Chemical compositions (in $\mathrm{g} \mathrm{kg}^{-1}$ ) of the different poultry manure composts

\begin{tabular}{crrr}
\hline Property & Cockerel Manure & Broilers Manure & Layers Manure \\
\hline Total Nitrogen & 22.40 & 34.30 & 24.00 \\
Organic Carbon & 222.50 & 381.30 & 248.00 \\
$\mathrm{C} / \mathrm{N}$ & 9.93 & 11.12 & 10.33 \\
$\mathrm{P}$ & 15.50 & 18.30 & 16.30 \\
$\mathrm{Ca}$ & 26.60 & 31.60 & 29.30 \\
$\mathrm{~K}$ & 12.10 & 13.90 & 12.50 \\
\hline
\end{tabular}

This was in agreement with the works of Isitekhale et al. (2013) for tomato, Eghball et al. (2004) and Farhad et al. (2011) for maize that gave highest plant height in soils treated with poultry compost. The long-lasting effect exhibited by the added compost could be responsible; while least values were recorded in plots without amendment.

Similarly, higher stem girth values of maize plants were recorded in the dry than wet seasons at weeks 2, 4 and 6 after planting. Maize crop is nutrient-demanding (Awe et al., 2014); much of the soil nutrients might have been utilized during the dry season cultivation. At 8 WAP, significantly $(\mathrm{p}<0.05)$ highest stem girth values obtained in the dry season were comparable with the wet season. The maize crop residues from the previous harvest required time to decay and mineralize before use by the maize plants in the subsequent season.

Gradual increase in the number of leaves of maize was obtained from 2 to 8 WAP for all the treatments. Plots treated with BM in the dry season had the highest number of leaves (15), and equal number of leaves was obtained in the wet season from the plots with IF. As expected, the control plots had the lowest values during the two seasons. Similar results of increased number of leaves and enhanced leafy productivity were given by 
Okokoh and Bisong (2011) when poultry manure and urea-N fertilization were compared, though with grain amaranth as the test crop.

\section{Dry Season}

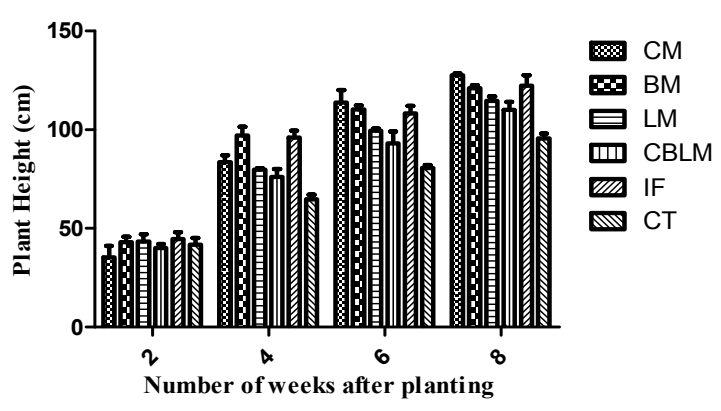

(b)

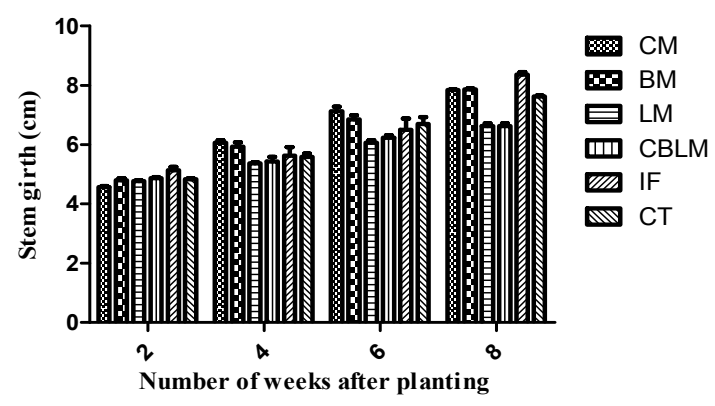

(c)

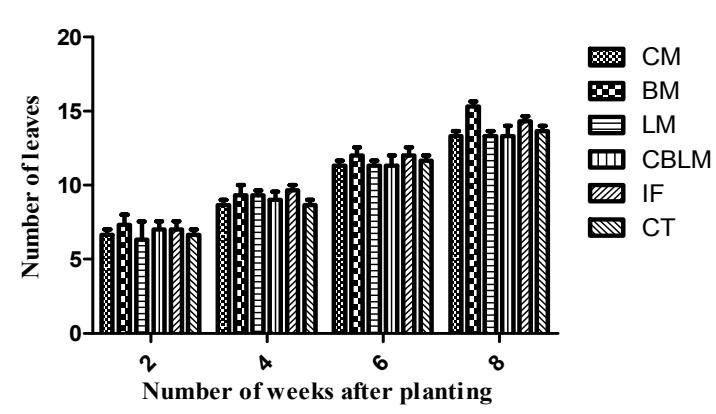

(a)

\section{)}

\section{Wet Season}
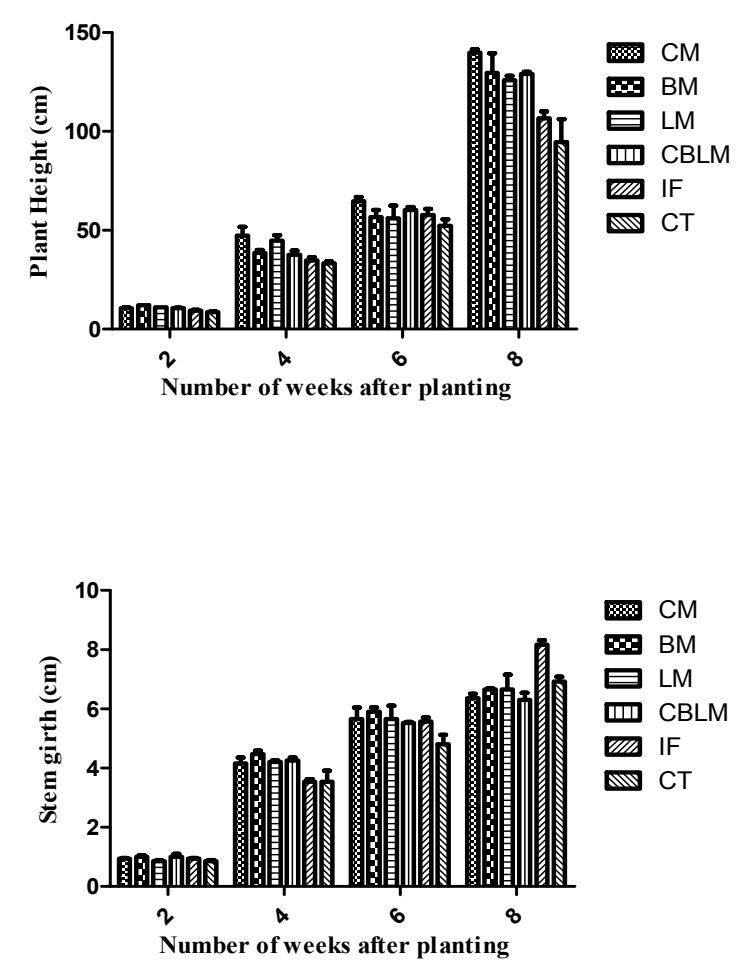

Figure 2(a)-(c): (a) Mean plant height; (b) mean stem girth and (c) mean number of leaves under different composted poultry manures and inorganic fertilizer for dry and wet seasons. Vertical bars represent the SE Legend: $\mathrm{CM}=$ Cockerel composted manure, $\mathrm{BM}=$ Broiler composted manure, $\mathrm{LM}=$ Layers' composted manure, $\mathrm{CBLM}=$ Cockerel + Broiler + Layer composted manure in equal proportions, IF $=$ Inorganic fertilizer and CT $=$ Control

\subsection{Yield Components and Yield of Maize}

The apparent efficiency of nitrogen recovery (AENR) was highest with BM (18.14\%), and closely followed by LM (17.59\%); while IF had the least (10.00\%) (Table 3). The AENR values obtained with different poultry 
compost applications were higher than with NPK inorganic fertilizer application. The implication of this was that N-release from the imposed poultry composts was optimally used due to its slow release over a longer period when compared with lower AENR value for IF. The order of $\mathrm{N}$ release by these applied treatments was in the order: $\mathrm{BM}>\mathrm{LM}>\mathrm{CM}>\mathrm{CBLM}>\mathrm{IF}$.

Grain yield of maize was a function of interaction among various yield components and these components are affected by sources and pattern of nutrients release, particularly $\mathrm{N}$ addition (Farhad et al., 2011) and ear-leaf $\mathrm{P}$ (Adeoye and Agboola, 1985). The N and P ear-leaf (NPEL) contents in maize plant are presented in Table 4. The NPEL contents obtained were in the order: BM $>$ CM $>$ LM $>$ CBLM $>$ IF $>$ CT. The higher the NPEL of the test crop, the higher was the grain yield obtained. Adeoye and Agboola (1985) earlier observed a direct relationship between ear-leaf $\mathrm{P}$ and grain yield of maize when cultivated on sedimentary soils of southwestern Nigeria. However, the highest mean grain yield of $1.30 \mathrm{t} \mathrm{ha}^{-1}$ obtained with the application of BM treatment was not significantly $(\mathrm{p}>0.05)$ different from the mean yield obtained with other treatments in the dry season (Table 5.) Also, comparable and higher yields of maize grain which were not significantly $(\mathrm{p}>0.05)$ different were obtained in the subsequent wet season.

The slight increase in the grain yield of maize in the wet season could be due to enhanced soil fertility from maize crop residual effects of the previous cropping and increased water supply. The increased soil moisture would enhance the availability and mobility of soil nutrients than in the dry season; an added advantage for increased grain yield. These results agreed with the observation on the residual effects of cattle manure by Silva et al. (2003) and poultry manure by Reddy et al. (2004) and Hirzel et al. (2007) on the grain yield of maize.

Table 3. Effect of applied $\mathrm{N}$ concentrations in different treatments on the apparent efficiency of $\mathrm{N}$ recovery (2012-2013)

\begin{tabular}{lcccc}
\hline Treatment & $\mathrm{N}_{\text {treatment }}$ & $\begin{array}{l}\mathrm{N}_{\text {control }} \\
\left(\mathrm{kg} \mathrm{ha}^{-1}\right)\end{array}$ & $\mathrm{N}_{\text {applied }}$ & $\begin{array}{c}\text { AENR } \\
(\%)\end{array}$ \\
\hline CM & $4,533.31$ & $2,799.98$ & 134.40 & 12.90 \\
BM & $6,533.29$ & $2,799.98$ & 205.80 & 18.14 \\
LM & $5,333.30$ & $2,799.98$ & 144.00 & 17.59 \\
CBLM & $4,666.64$ & $2,799.98$ & 160.83 & 11.61 \\
IF & $3,733.31$ & $2,799.98$ & 93.33 & 10.00 \\
CT & $2,799.98$ & $2,799.98$ & - & - \\
\hline
\end{tabular}

Legend:

$\mathrm{CM}=$ Cockerel composted manure, $\mathrm{BM}=$ Broiler composted manure, $\mathrm{LM}=$ Layers' composted manure, $\mathrm{CBLM}$ $=$ Cockerel + Broiler + Layer composted manure in equal proportion, IF $=$ Inorganic fertilizer, CT $=\mathrm{Control}$, $\mathrm{N}_{\text {treatment }}=$ Nitrogen uptake in the applied treatments, $\mathrm{N}_{\text {control }}=$ Nitrogen uptake in the control, $\mathrm{N}_{\text {applied }}=$ Applied Nitrogen, and AENR = Apparent Efficiency of Nitrogen Recovery.

Table 4. Mean $( \pm$ S.E) concentration of nitrogen and phosphorus in maize plant at tasselling stage

\begin{tabular}{lll}
\hline Treatment & $\mathrm{N} \mathrm{g} \mathrm{kg}^{-1}$ & $\mathrm{P} \mathrm{mg} \mathrm{kg}^{-1}$ \\
\hline $\mathrm{CM}$ & $3.01 \pm 0.22$ & $0.50 \pm 0.06$ \\
$\mathrm{BM}$ & $3.75 \pm 0.31$ & $0.77 \pm 0.05$ \\
$\mathrm{LM}$ & $2.55 \pm 0.24$ & $0.46 \pm 0.12$ \\
$\mathrm{CBLM}$ & $2.53 \pm 0.20$ & $0.51 \pm 0.04$ \\
$\mathrm{IF}$ & $2.21 \pm 0.11$ & $0.39 \pm 0.11$ \\
$\mathrm{CT}$ & $1.01 \pm 0.15$ & $0.18 \pm 0.04$ \\
\hline
\end{tabular}

Legend:

$\mathrm{CM}=$ Cockerel composted manure, $\mathrm{BM}=$ Broiler composted manure, $\mathrm{LM}=$ Layers' composted manure, $\mathrm{CBLM}$ $=$ Cockerel + Broiler + Layer composted manure in equal proportion, $\mathrm{IF}=$ Inorganic fertilizer and $\mathrm{CT}=\mathrm{Control}$ 
Table 5. Mean grain yield $\left(\mathrm{tha}^{-1}\right)$ of maize for dry and wet seasons

\begin{tabular}{lll}
\hline Treatment & $\begin{array}{l}\text { Dry } \\
\text { season }\end{array}$ & $\begin{array}{l}\text { Wet } \\
\text { season }\end{array}$ \\
\hline CM & $1.17^{\mathrm{a}}$ & $1.50^{\mathrm{a}}$ \\
BM & $1.30^{\mathrm{a}}$ & $1.78^{\mathrm{a}}$ \\
LM & $0.97^{\mathrm{a}}$ & $1.47^{\mathrm{a}}$ \\
CBLM & $0.82^{\mathrm{a}}$ & $1.57^{\mathrm{a}}$ \\
IF & $1.23^{\mathrm{a}}$ & $1.11^{\mathrm{a}}$ \\
CT & $0.74^{\mathrm{a}}$ & $1.10^{\mathrm{a}}$ \\
\hline
\end{tabular}

Mean with the same superscript within the same column do not differ significantly at $\mathrm{p}<0.05$

Legend:

$\mathrm{CM}=$ Cockerel composted manure, $\mathrm{BM}=$ Broiler composted manure, $\mathrm{LM}=$ Layers' composted manure, $\mathrm{CBLM}$ $=$ Cockerel + Broiler + Layer composted manure in equal proportion, $\mathrm{IF}=$ Inorganic fertilizer and $\mathrm{CT}=$ Control

\section{Conclusion}

We concluded that single application of aerobically composted poultry manure, particularly compost from the broiler birds had highest residual effect and could serve as alternative nutrients source as against the conventional inorganic NPK fertilizer use for optimum production of maize grains. We also concluded that the grain yield of the test crop, maize, performed optimally in the wet than dry seasons, it's drought-tolerant attributes notwithstanding.

\section{Acknowledgements}

The authors are grateful to Prof. S. A. Olakojo, Head, Cereals Improvement Program, Institute of Agricultural Research and Training, Obafemi Awolowo University, Moor Plantation, Ibadan, Nigeria for providing us with the viable maize variety (DT-SR- $\mathrm{WC}_{2}$ ) seeds and space for the research work in the Institute Teaching and Research Farm at Ilora Substation, Ilora, Nigeria.

\section{References}

Adeoye, G. O., \& A. A. Agboola. (1985). Critical levels for soil PH, available P, K, Zn and Mn, and maize ear-leaf content of $\mathrm{P}, \mathrm{Cu}$ and $\mathrm{Mn}$ in sedimentary soils of South-western Nigeria. Fertilizer Research, 6, 65-71. http://dx.doi.org/10.1007/BF01058165

Adeoye, G. O., Omueti, J. A. I., Sridhar, M. C. K., Hassan, U. A., John, N. M., Ogazi, J. N., Sule, A., \& Olajuyigbe, O. (1995). A case study of organomineral fertilizer in different ecological zones of Nigeria. A paper presented at the $3^{\text {rd }}$ All African soil science society conference held at the university of Ibadan, Ibadan, Nigeria on August 19-20, 1995.

Adewole, M. B., \& Dedeke, A. O. (2012). Growth performance, yield and nutritional quality of Amaranthus cruenthue L. under repeated applications of poultry manures. Ife Journal of Science, 14(2), 345-355.

Alvarez, R., \& Grigera, S. (2005). Analysis of soil fertility and management effects on yields of wheat and corn in the Rolling Pampa of Argentina. Journal of Agronomy and Crop Science, 191, 321-329. http://dx.doi.org/10.1111/j.1439-037X.2005.00143.x

Awe, A. O., Okareh, O. T., \& Sridhar, M. K. C. (2014). Use of processed waste feathers as source of organic nutrients for maize production. African Journal of Environmental Health Sciences, 1(1), 9-13.

Ayoade, J. O. (2011). Introduction to climatology for the tropics. Spectrum books limited, Ibadan, Nigeria. pp 297.

Boateng, S., Zickermann, A. J., \& Kornaharens, M. (2006). Effect of poultry manure on growth and yield of maize. West African Journal of Applied Ecology, 9, 1-11

Daramola, D. S., \& Taiwo, L. B. (2008). Effects of equvalent replacements of inorganic $\mathrm{N}$ with organic $\mathrm{N}$ on the growth and $\mathrm{N}$ uptake of maize (Zea mays). Moor Journal of Agricultural Research, 9, 26-34.

Eghball, B., Ginting, D., \& Gilley, J. E. (2004). Residual effects of manure and compost applications on corn production and soil properties. Agronomy Journal, 96, 442-447. http://dx.doi.org/10.2134/agronj2004.0442 
Farhad, W., Saleem, M. F., Cheema, M. A., \& Hammad. H. M. (2009). Effect of poultry manure levels on the productivity of spring maize (Zea mays L.). The Journal of Animal and Plant Sciences, 19(3), 122-125.

Hirzel, J., Matus, I., Novoa, F., \& Walter, I. (2007). Effect of poultry litter on silage maize (Zea mays L.) production and nutriet uptake. Spanish Journal of Agricultural Research, 5(1), 102-109. http://dx.doi.org/10.5424/sjar/2007051-226

IITA. (2001). Annual report on maize production by International Institute of Tropical Agriculture, Ibadan, Nigeria. pp 50. old.iita.org/cms/articlefiles/275-IITA_AR_2001.pdf. Accessed 04/02/2015.

Isitekhale, H. H. E., Osemwota, I. O., \& Amhakhian, S. O. (2013). Poultry manure and NPK fertilizer application and their residual effects on the yield and yield components of tomato (Lycopersicon esculentus Mill.) in two distint ecological zones of Central Southern Nigeria. Journal of Agriculture and Veterinary Science, 3(2), 40-47. http://dx.doi.org/10.9790/2380-0324047

Kogbe, J. O. S., \& Adediran J. A. (2003). Influence of nitrogen, phosphorus and potassium application on the yield of maize in the savanna zone of Nigeria. African Journal of Biotechnology, 2(10), 345-349. http://dx.doi.org/10.5897/AJB2003.000-1071

Li, Y. P., Ye, W., Wang, M., \& Yan, X. D. (2009). Climate change and drought: a risk assessment of crop-yield impacts. Climatology Research, 39, 31-46. http://dx.doi.org/10.3354/cr00797

Odjugo, P. A. O. (2010). General overview of climate change impacts in Nigeria. Journal of Human Ecology, 29(1), 47-55.

Odjugo, P. A. O. (2011). Climate change: Evidence, impacts and adaptation strategies in Nigeria. In Ayobami T. Salami, \& Olugbenga O. I. Orimoogunje (Eds.), Environmental research and challenges of sustainable development in Nigeria (pp. 142-164). Obafemi Awolowo University Press, Ile-Ife, Nigeria.

Ogunsumi, L. O., Ewuola, S. O., \& Daramola, A. G. (2005). Socio-Economic Impact Assessment of Maize Production Technology on Farmers' Welfare in South West, Nigeria. J. Central Eur. Agric, 6(1), 15-26.

Okokoh, S. J., \& Bisong, B. W. (2011). Effect of poultry manure and urea-N on flowering occurrence and leaf productivity of Amaranthus cruentus. Journal of Applied and Environmental Science Management, 15(1), 13-15.

Oladejo, J. A., \& Adetunji, M. O. (2012). Economic analysis of maize (Zea mays L.) production in Oyo state of Nigeria. Agricultural Science Research Journals, 2(2), 77-83.

Otitoju, O. M. (2014). Comparative effects of organic and inorganic fertilizer applications on growth performance, yield and nutrient quality of a drought-tolerant maize variety. M.Sc. thesis submitted to the Institute of Ecology and Environmental Studies, Obafemi Awolowo University, Ile-Ife, Nigeria. pp 158.

Page, A. L., Miller, R. H., \& Keeney, D. R. (1982). Methods of soil analysis, Part 2, Chemical and Microbiological properties. American Society of Agronomy, Inc., Madison, WI.

Reddy, S. S., Shivaraj, B., Reddy, V. C., \& M. G. Ananda. (2004). Effect of direct and residual fertility and yield components of maize (Zea mays L.). Karnataka Journal of Agricultural Sciences, 17(4), 676-681.

Rees, R., \& Castle, K. (2002). Nitrogen recovery in soils amended with organic manures combined with inorganic fertilizers. Agronomie, 22, 739-746. http://dx.doi.org/10.1051/agro:2002061

Schittenhelm, S., \& Schroetter, S. (2014). Comparison of drought tolerance of maize, sweet sorghum and sorghum-Sudangrass hybrids. Journal of Agronomy and Crop Science, 200, 46-53. http://dx.doi.org/10.1111/jac.12039

Silva, P. S. L., Silva, J., Olivera, F. H. T., Sousa, A. K. F., \& Duda, G. P. (2006). Residual effect of cattle manure application on green ear yield and corn grain yield. Horticultura Brasileira, 24, 166-169. http://dx.doi.org/10.1590/S0102-05362006000200008

Tsai, C. Y., Huber, D. M., Glover, D. V., \& Warren, W. L. (1984). Relationship of N deposition to grain yield and $\mathrm{N}$ response of three maize hybrids. Crop Science, 24, 277-281. http://dx.doi.org/10.2135/cropsci1984.0011183X002400020016x

\section{Copyrights}

Copyright for this article is retained by the author(s), with first publication rights granted to the journal.

This is an open-access article distributed under the terms and conditions of the Creative Commons Attribution license (http://creativecommons.org/licenses/by/4.0/). 